\title{
USE OF AUTHENTIC VIDEO MATERIALS IN TEACHING ESP FOR FUTURE CIVIL ENGINEERS
}

\section{Konoplianyk Lesia ${ }^{1}$}

DOI: http://dx.doi.org/10.30525/978-9934-571-27-5_23

\begin{abstract}
The purpose of the paper is to investigate the role of using the authentic video maerials in ESP classes at a higher school for enhancing future civil engineers' professional communication in English and improving their English proficiency. The paper provides a brief overview of how "authentic" is defined by other authors, clarifies the notion of the "authentic material", indicates what factors determine the authentic nature, describes the special features of using video materials in ESP classes, determines their possible advantages (e.g. creating specific language environment, increasing motivation and attention, developing memory, activating the learning process, etc), disadvantages and main challenges. The research also outlines the criteria of the selection of the video in an ESP class (authenticity; compliance with the curriculum, syllabus, thematic correspondence to students' specialty and their interests; information novelty and relevance; the correspondence of language material to speech rules and students' level of knowledge, and their readiness to perceive information from the video; appropriate length of the video; image and sound quality of the chosen video). The author defines the objectives and special features of the pre-viewing, while viewing and post-viewing stages of the work with authentic video materials, offers the typology and complex of tasks used at each stage. The pre-viewing tasks are designed to introduce new vocabulary to students, practice new vocabulary in lexical exercises, practice predicting the plot and speculating about the content of the video segment which is going to be watched, generate interest in a topic and initiate authentic discussion. The while viewing tasks are designed to search information, select and transform a language material, develop receptive skills, as well as communication, social and cultural skills. The post-viewing tasks are aimed at discussing the topic and developing the speaking skills (both monologue
\end{abstract}

${ }^{1}$ Candidate of Pedagogical Sciences,

Associate Professor at the Department of Foreign Languages and Applied Linguistics, National Aviation University, Ukraine 
and dialogue speech) and writing skills (both reproductive and productive). The paper includes several examples from the author's own practice, a set of tasks for the work with the video segment used for the training students majoring in civil engineering and suggestions for follow-up activities.

\section{Introduction}

Ukraine's participation in the European integration processes, expansion of its foreign contacts in the field of civil engineering and the increase of the level of scientific and technical cooperation with foreign partners put forward certain requirements for the professional training of highly skilled civil engineers. Modern engineers have to adapt quickly to the rapid changes in living and working conditions, which require continuous training and professional development, self-improvement and development of their professional competence. In their future professional activity, civil engineers will have to study and apply foreign experience, learn innovative projects, inventions and discoveries in the construction industry, get acquainted with scientific, technical and professional literature in English, and maintain business contacts with foreign partners. Therefore, the role of professional communication in English for future civil engineers is increasing. The formation of professional competence of a future civil engineer requires improving the content, forms and methods of language teaching at a higher school.

It is quite difficult to form students' foreign language communicative competence when there is no natural environment of communication. Therefore, it is extremely important to find methods, forms and means of teaching, as well as new types of visualization to create real and imaginary situations of communication in ESP (English for Specific Purposes) classes, which would result in increasing productivity and activating the learning process. The methodology of teaching a foreign language is based on the principle, according to which students' learning of a foreign language as a means of intercultural communication is possible only in the context of communication similar to real one $[12$, p. 56]. The simulation of real communication using role-plays, case study, discussions and other interactive methods in ESP classes facilitates ESP learning and develops speaking skills. However, apart from speaking, students need to hear native speakers, and this problem is especially urgent in the absence of the natural communication environment in the classrooms of Ukrainian higher schools. In this 
case, the authentic video material is an essential resource. The rich authentic material containing natural communicative situations and an interesting plot makes the learning process more natural, informative and interesting.

The use of authentic video materials in ESP classes offers a number of unique opportunities for teachers and students, since it allows them not only to improve English but also to gain additional professional knowledge and discover foreign culture for themselves. The analysis of investigations into the importance of using authentic video materials in ESP classes has shown that their use has a positive impact on the formation of future specialists' foreign language communicative skills (O. Kochukova, T. Leontieva, A. Muntian, Yu. Trykashna, M. Mekheimer, E. Tschirner, J. Weyers); facilitates vocabulary expansion (Yu. Verysokin, N. Schmitt), develops speaking skills (N. Bychkova, K. Volchenkova, Ya. Semenova, E. Tschirner) and listening skills (H. Huniashova, S. Herron, I. Seay, J. Weyers); enhances intercultural communication (O. Zelenska, R. Gower, D. Phillips, S. Walters); increases students' motivation and activity (S. Samoilenko, O. Shtelmakh, S. Steapleski) and others. Emphasizing the positive effect of using authentic video materials in learning a foreign language, N. Kovalenko, Yu. Kolbysheva, H. Miasoiid, A. Hrytsai and I. Kolesnik have devoted their investigations to the main stages of activities with video materials and the use of different types of tasks at these stages.

The analysis of the aforementioned investigations testifies to the successful application of authentic video materials in the educational process to develop foreign language communicative competence, increase motivation of language learning and is inexhaustible resource of teaching materials. However, the aspects of using authentic video materials in the process of teaching future civil engineers in the ESP classes have not been studied sufficiently and implemented in practice. Before creating the effective technologies for working with such materials the following steps should be done: well-considered selection of authentic video materials, evaluation of educational objectives to apply such materials and development of the system of tasks.

Thus, the paper aims at studying the possibilities of using authentic video materials in ESP classes to enhance future civil engineers' professional communication in English. The realization of this goal involves solving the following tasks:

1) to reveal the peculiarities of the use of authentic video materials in ESP classes, their advantages, drawbacks and challenges; 
2) to substantiate the criteria for the selection of the authentic video, resources and types of video materials that can be used in teaching future civil engineers;

3) to outline the main stages of work with authentic video material in ESP classes and indicate their special features;

3) to devise the typology of video materials used at different stages and indicate their objectives.

\section{The concept of an authentic material and its objectives}

Professional communication in English requires students' mastery of the following skills: speaking skills, listening skills, reading skills and writing skills, which allow receiving the relevant professional information in English in order to use it to express their opinion competently during verbal and non-verbal interaction in their future professional activity.

The use of authentic video materials is one of the techniques that contribute to the development of foreign-language professional communication skills in ESP classes. Unlike printed authentic materials, which undoubtedly have high informative, educational and cognitive value, the video material also contains visual information in addition to the content. According to M. Isupova, visual elements allows students to understand better both factual information and linguistic peculiarities of the language in a definite context, because the visual support of a foreign-language sound series contributes to a deeper and more accurate understanding of its meaning and the development of students' phonemic and listening skills [4, p. 150].

Since using authentic materials in ESP classes is increasing nowadays, we will try to explain what the term of "authentic material" means.

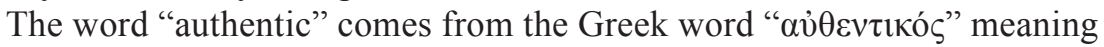
"true, valid, real, and genuine". R. Gower, D. Phillips, D. and S. Walters proposed the following definition to the term: "Everything that a native speaker hears, reads or uses can be described as authentic: theatre programme, newspapers, magazines, poems, songs, brochures, leaflets, menus, broadcasts and movies, and this list can be continued indefinitely. Since authentic materials have not been designed for students studying English as a foreign language, they are not classified in terms of levels, although some of them are harder to understand than others" [15, p. 82]. T. Adams [13], S. Bacon and M. Finnerman [14, p. 464] and J. Harmer $[16$, c. 273$]$ consider that materials that have been originally created by 
native speakers for native speakers but not intentionally for educational purposes can be called authentic materials.

Ukrainian researchers agree with the foreign ones. O. Zelenska states that authentic materials are oral and written texts and other materials that are the real pro-ducts of native speakers, and they are not intended for teaching purposes and are not adapted for students' needs, taking into account their proficiency in English [2, p. 156]. Summarizing the information mentioned above, we conclude that authentic materials are original materials (print and auditory) encountered in the real daily life which have been created by native speakers for real communication conditions but not for teaching purposes.

Working with authentic video materials one can fulfill various objectives depending on the tasks assigned to the class. These objectives include: vocabulary expansion (introduction of new words and phrases or summarizing the words and phrases studied before); development of listening skills (learning to understand the speech of native speakers); study of grammar (presentation of a new material or summarizing the grammar material studied before); pronunciation work (pronunciation of certain sounds, imitation of intonation); introduction to the communicative situation and the expansion of students' professional knowledge, etc.

It should be noted that the use of authentic video materials in ESP classes is an effective means of familiarizing students with cultural, historical, ethnographic realities of the English-speaking countries, world-famous engineering structures and constructions, modern engineering structures, innovations in the field of the construction industry. Such materials are interesting for students, informative and they contain real data. In our opinion, the use of such materials increases students' interest in their future profession, forming their professional, communicative and intercultural competences.

\section{Advantages, drawbacks and challenges of using authentic videos}

The analysis of previous investigations into the issue of using authentic video materials while learning English and our own experience of working with such materials in ESP classes at the National Aviation University, have assisted to conclude that a set of didactic tasks can be solved by using authentic video materials. The advantages of using authentic video materials in ESP classes include: 


\section{Use of authentic video materials in teaching ESP for future civil engineers}

1. Creating the specific language environment. Authentic video materials are essential for creating the specific language environment in ESP classes at technical universities if there is no natural environment for communication in English. Due to the watching of a video, students (future civil engineers) can find themselves among the experts of the construction industry working on a particular project, participating in the construction process of an engineering structure, or observing the history of the construction of a remarkable engineering structure.

2. Increase of students 'motivation. The use of authentic video materials in ESP classes increases the motivation for learning and creates certain conditions close to quasi-communicative, learning, research and creative activities of students [3, p. 1961]. First of all, students get positive emotions when they comprehend the material, created for native speakers, and note that ESP is achievable for them. Secondly, they show greater interest when they observe the use of the English language in real situations of professional communication, and this motivates them more than any other factor. And, finally, a carefully selected video material and appropriate tasks to this material encourage students to participate actively in a roleplay or discussion that take place after viewing, search for new or additional information on a particular topic and result in activating students' cognitive activity.

3. Matching students 'interests. Authentic video materials are interesting and stimulating for students. Moreover, they can be selected in accordance with the students' interests and specialty; moreover, students can participate in selecting the material.

4. Exact representation of the language in use. On the basis of video materials students can listen and study the live speech of native speakers. Students are exposed to real language in the natural context. The full authenticity of the linguistic material means that it is not simplified; the characters in a video extract speak with the accent typical to certain locality, but common phrases and idioms are used as well. Visual information helps students comprehend the language better than using only audio files.

In addition, authentic video materials reflect the real use of language in the cultural context and allow students to familiarize themselves with the traditions of relationships and culture of other countries. The exact representation of the language in use is achieved due to the fact that it is used by native speakers, closely related to a certain language situation, and its 
communicative purpose is supplemented by a body language (poses, facial expressions, gestures) [5, p. 32].

5. Development of students' attention and memory, effective learning of the material. The use of video materials in ESP classes contributes to the development of various aspects of students' mental activity. First of all, this concerns attention and memory, because when the video material is viewed in a classroom among audience, the atmosphere of cognitive activity is created, and even an inattentive student becomes attentive in such conditions [9, p. 357]. Students have to make some efforts to understand the video content, so non-volitional attention eventually turns into volitional one, and attention intensity affects the memorizing process. Simultaneous use of several channels of information intake (auditory, visual and motor perception) when viewing videos has a positive effect on memorizing new lexical units and learning the material related to future profession [11, p. 106].

6. Involvement in cultural realities of other countries including English-speaking ones. Authentic video materials provide with almost unlimited opportunities for analysis based on comparisons of cultural realities of other countries, and therefore they are invaluable teaching materials for forming productive foreign language communicative and socio-cultural competencies [3, p. 1961].

Despite the value of authentic video materials as a means of learning English, sometimes the work with them include only viewing the video and its further discussion. It should be noted that there is no systematic approach today to work with video materials in ESP classes, although such material can be an inexhaustible source of information that facilitates the development of students' new knowledge and skills.

While planning ESP classes applying authentic video materials, teachers face several challenges. They should become fluent Internet surfers to find the desirable authentic video, should think over how to implement and integrate the chosen video material into ESP classes and what activities to suggest, and what feedback from students to expect. Scientists and teachers emphasize the following challenges when organizing their work with authentic video materials in ESP classes.

1. The difficulty of the video material. This may be caused by the wrong choice when the linguistic material contained in the authentic video is too difficult for students to understand and does not correspond to the partic- 
ular learning tasks, because the vocabulary of this linguistic material goes beyond the subject being studied or students' specialty.

2. The complexity of video perception by students. Authentic video materials do not always guarantee that all students in the classroom will get the same information. The inability of students to understand certain authentic video material can be caused by the lack of knowledge of English or the specialty, improper work before viewing, or by the video that is too long. Therefore, the teacher must select the appropriate material that matches the interests of students and eliminate the language difficulties of perceiving the video before viewing through the tasks he/ she has previously developed. And, undoubtedly, the video must be accompanied by clear teacher's instructions.

3. The time factor. Despite the fact that the Internet provides with a wide range of video materials, a teacher needs to spend a lot of time preparing for ESP classes using such materials. It is necessary to find the appropriate material, work it out and create a system of tasks that can be a time-consuming and difficult process.

4. The factor of novelty and urgency. In the modern fast-developing world, some of the authentic materials quickly become outdated. Information that is considered new today may turn out to be irrelevant and uninteresting for students tomorrow. Therefore, the teacher should be constantly looking for relevant materials for students.

So, these challenges constitute the drawbacks of using authentic video in ESP classes, which a teacher can encounter. First of all, it is not an easy task to find an appropriate material, and this task is time-consuming. Secondly, not all classrooms are equipped with appropriate devices, so the teacher has to think himself/ herself about the required equipment. Moreover, any technical problem with equipment can impede teacher's efforts. And finally, the chosen material can provoke less students' interest that has been expected by a teacher and disappoints him / her. However, all the points mentioned above cannot ruin the benefits of such materials.

Thus, the teacher should be aware of the challenges in using authentic video material in ESP classes and should:

a) carefully select video material that matches students' interests and needs;

b) eliminate language difficulties of perception and understanding of the video material with the help of the pre-viewing tasks; 
c) create tasks that would attract and support students' interest and the desire to discuss the material (post-viewing).

The use of authentic video materials requires the offective organization of students' learning, preliminary and gradual students' preparation for such kinds of work in ESP classes. That is, it is necessary to organize students' studying so that they would enjoy viewing the segment from the movie, not only because of its interesting plot, but also due to the understanding of a foreign language.

\section{Authentic video in ESP classes: selection criteria, sources and types}

The teacher's work with authentic video material starts its search and choice. It is very important to choose the appropriate video material for ESP classes. To make the use of authentic video materials effective, the following conditions must be met:

- the content of the video material should be informative and correspond to the themes in the curriculum, syllabus, students' interests and their level of knowledge;

- the video material must be used and displayed in the scheduled and relevant time [3, p. 1961];

- the video segment should provide students with the opportunity to develop their linguistic, communicative, and socio-cultural competencies [3, p. 1961];

- the video must be accompanied by clear teacher's instructions aimed at solving a certain educational task and be understood by students;

- the video segment should not be too long.

Thus, the following criteria for choosing the appropriate authentic video material can be considered as the most important ones:

- authenticity,

- compliance with the curriculum, syllabus, thematic correspondence to students' specialty and their interests,

- information novelty and relevance,

- the correspondence of language material to speech rules and students' level of knowledge and their readiness to perceive information from the video,

- the length of the video,

- high-definition image and high-quality sound in the video, etc.

Unfortunately, there are no specially designed video materials for future civil engineers today. While working with them we have used: 
- segments of documentaries from Discovery Channel, Natural Geographic ("Mega Engineering", "London Heathrow Airport”, "Lupu BridgeMegastructures", "Secrets of the Taj Mahal", "Superstructures - Eurotunnel", "Megabridges - Denmark to Sweden", "Dynamic Architecture", "World's First Round Skyscraper", "Basilica of the Sagrada Familia. Welcome to the Temple", etc);

- 4-5 minute reports of the BBC News, CNN and CBS related to civil engineering ("Iconic Tower of Pisa now one Inch Straighter" (CBS news), "The Millennium Bridge - what caused the wobble?" (BBC news), etc);

- segments of shows on Netflix ("Building Hong Kong's Airport", "Oak-land Bay Bridge", "Millau Viaduct", etc)

- materials of TED Talks ("Why do buildings fall in earthquakes?", "Building the Seed Cathedral", etc)

- segments of movies ("The Architect").

Since segments of documentaries are very informative, lasting up to 15-20 minutes and containing a lot of information necessary for processing, we divide their viewings into several parts and try to organize the work so as not to overload the students' memory. News reports usually last 4-5 minutes, so there is no need to divide them into several parts.

\section{Stages of work with authentic video materials}

The ESP classes with the use of authentic videos related to future professional activities of students majoring in civil engineering consist of the following traditional stages:

- pre-viewing (or preparatory stage according to the functions and tasks of this stage),

- while viewing,

- and post-viewing.

Each stage has its own typology of exercises (tasks), although some of them can repeat at different stages.

The pre-viewing (or preparatory stage) is the stage of psychological preparation of students for the perception of video in English. The main objectives of this stage are: to motivate students, overcome possible language difficulties of perception of the video content and simplify its understanding, prepare students for viewing video and doing tasks successfully $[8$, p. 70$]$. At this stage, new lexical units are represented, the understanding of the previously learned lexical and grammatical mate- 
rial is checked, unfamiliar authentic conversational phrases are analyzed, socio-psychological background and content guidelines are formed for further perception of the form and content of the video or its segment $[6$, p. 86]. Therefore, the tasks that are done before watching the video, allow developing the listening skills that will help perceive the foreign speech in the video.

When viewing a video in a native language, students usually do not have any difficulties in perceiving information, whether they are guessing in advance about what is going on or not. However, when viewing authentic video in English, some problems arise due to the use of unfamiliar words and grammatical constructions, the rapid pace of speech (as the video is not adapted to a certain level of students' knowledge). The situation is even more complicated if students do not know the topics discussed in the video. Therefore, a simple viewing of such a video with subsequent answering the question to its content will not be of great importance and will make the development of listening skills much more complex or even impossible for some students. It is known that many students are afraid of listening because they are very embarrassed by the fact that they do not understand the material used for listening. In addition, it is very difficult for a student to focus on listening to or watching the material they are not interested in. Therefore, the tasks offered at this stage should:

- focus students on a certain topic;

- activate existing knowledge on this topic;

- facilitate obtaining new knowledge to increase self-confidence during viewing (in the form of reading a text on similar topics or having a quiz);

- represent new vocabulary to students and practice it by using lexical exercises in order to avoid distracting students while watching the video by unfamiliar vocabulary);

- represent unfamiliar grammar constructions and overcome phonetic difficulties.

The following exercises (tasks) can be appropriate at this stage:

- read and translate the words, word combinations and phrases that will be mentioned in the video segment; make a phrase from the words; give a definition to the following words; match the words with their meanings; write synonyms, antonyms to the following words; fill in the gaps with the words; etc (the objective of these tasks is to represent new vocabulary to students, practice it and overcome language difficulties); 


\section{Use of authentic video materials in teaching ESP for future civil engineers}

- name the words that are associated with the topic; read the title and pre-dict (guess) the content of the video; read the questions to the video and predict its content and topic; define the subject of the video by looking at the list of new words; look at the title of the video and say what you have already known about this topic or what you would like to know; find information related to the plot of the video; make a mind map of the basic concepts (keywords and phrases) of the problem to which the video is devoted; before viewing try to identify if the following statement are true or false using your knowledge; read and discuss the text on similar topics; etc (the objective of these tasks is to actualize the vocabulary from the theme of the video and practice speculating and predicting video content, generate students' interest in the topic and initiate authentic discussion). However, it is important to prepare students for viewing, but not to reveal the entire content of the video at this stage; otherwise, it can result in decreasing students' interest in the video.

We have developed a set of tasks for CBS News report entitled "The Leaning Tower of Pisa one inch straighter", which are used while studying the topic "Foundation" by the students majoring in civil engineering and which were represented in the paper [7, p. 118-119] and the tutorial "Professional English of the Construction Industry" [10, p. 66-69]. They include the following pre-viewing tasks:

Exercise 1. Answer the following questions (Have you ever been to Italy? Have you visited the Leaning Tower of Pisa? What is it famous for? Does the Bell tower of Pisa lean due to the special construction or a faulty foundation or an architect's project or the architectural style? (Circle the correct option).

After representing the new vocabulary to the video we propose students to do the exercises as follows: Exercise 2A. Match the words on the left with their definitions on the right. Exercise 2B. Fill in the gaps with the following words.

Exercise 3. Brainstorming. Work in groups of three or four and discuss as future civil engineers what methods of tower strengthening can be used. Present your ideas to the whole group [7, p. 118; 10, p. 66-67].

While viewing students develop the abilities to perceive information and verify their understanding of the information, but this stage is also accompanied by their active learning activities. The purpose of this stage is to develop students' listening skills and language, speech and socio-cultural 
competence, taking into account their real capabilities to communicate in English, and to activate students' mental activity.

We propose to divide the work of the stage into two parts: the first and the second viewing. The first viewing is aimed at getting a general idea, general understanding and forming the skills of global understanding of the video. It is usually accompanied by informative exercises, which should not distract students from viewing (e.g. choose the right answer (multiple-choice), mark the correct answer, etc.). The second viewing (if required, pauses are made) is aimed at obtaining more detailed information and selective or detailed understanding of the text of the video (e.g. fill in the gaps in the sentences, fill in the table with the information from the video, put the sentences in the correct order, etc). The tasks used at this phase should facilitate a better understanding of the video content and active interaction with the video material as well as activate students' learning and cognitive activities. The teacher's task is to formulate clearly the communicative task. If the teacher is interested in the process of developing students' listening skills, then he/ she needs to give and explain the task before viewing, and if it is important to control students' understanding, the task should be given after viewing. For more detailed understanding of the video material, the video can be demonstrated with several pauses and divided it into parts.

The main tasks used at viewing stage are:

- match English equivalents to Ukrainian words and phrases; match Ukrainian equivalents to English expressions; fill in the gaps in the sentences / text with the required words; write the words from the list in the grammar form used in the video; pick up synonyms or antonyms to the words you hear; make a simultaneous translation of the episode (with pauses while viewing); write nouns, adjectives, adverbs, verbs that you will hear while viewing to describe certain objects, events, characters, etc.; determine what events in the video are related to these dates (these tasks are aimed at searching for linguistic information, selecting and transforming linguistic material);

- answer the questions; choose the right answer (multiple choice); tell if the following statements are true or false; put the events in the correct order according to the video content; fill in the table with information from the video; choose the most suitable headings to label the following episodes; divide the plot into several parts and choose the headings for each of them; name the participants in the dialogues; choose the correct ending for the 
utterance (these tasks are aimed at developing receptive skills by selecting content and semantic information [1, p. 78]);

- tell the story you have seen from the point of view of (a character from the video); give a detailed answer to the questions (these tasks are aimed at developing speaking skills (monologue and dialogue);

- compare the information you have watched with the realities of the Ukrainian construction industry; exercises on intercultural comparisons and the search for intercultural differences, interpretation of various situations in terms of cultural features of Ukraine (these tasks are aimed at developing social and cultural skills);

The checking of the tasks of the viewing stage is carried out as soon as they are completed. Doing tasks at this stage will contribute to a better understanding of the material and to the development of students' communicative skills.

The tasks we used for the video entitled "The Leaning Tower of Pisa one inch straighter" contain:

Exercise 1. Watch the Allen Pizzey's report for CBS News about the reconstruction project to help straighten the famous Italian landmark and tell if the statements below are true $(T)$ or false $(F)$. If they are false, correct them.

1. The Leaning Tower of Pisa isn't leaning so much these days.

2. The monumental reconstruction took 20 years.

3. The name Pisa dates from about 800 B.C....

Exercise 2. Who said the following lines? Write $R$ for reporter Allen Pizzey, TD for technical director Giuseppe Bentivoglio and T for tourists visiting the tower.

"For the next two or two-and-a-half centuries there will be no need for another intervention."

"Are you surprised of what you see?"

"I'm surprised that it isn't falling over."

"It's sensitive to the temperature and the wind, and especially to the underground layer of water, which varies depending on the season." ...

Exercise 3. Write notes about the dates and numbers below.

$\$ 40$ million 600 B.C. 180 feet $\quad 14,500$ metric tons $\quad 300$

Exercise 4. Watch the video again and answer the questions below.

1. How much is the tower straighter now?

2. How many years did the reconstruction project take? 
3. How many years can the Leaning Tower of Pisa be stable without intervention?

4. When did one side of the tower begin to sink?

5. What did the engineering project to correct the tilt involve? ... [7, p. 119; 10, p. 67].

The post-viewing is aimed at discussing the topic and developing the speaking skills (monologue and dialogue) and writing skills (reproductive and productive). It is relevant to suggest writing a composition or retelling based on the video content; make a dialogue between the characters of the video; have a discussion or debates; organize a role-play based on a plot or a situation from the video; rewrite a certain scene from the movie (what would happen if ...?); create a project related to the preparation of similar videos; find additional information on the topic; write a review of the video, etc. Students learn to express their own thoughts, compare, match, criticize and debate in discussions and role plays. Since the students' communicative and creative activity is intensified, the knowledge on a certain topic on the specialty is extended as well as the knowledge of a foreign language. As we can see, tasks performed after viewing are created not only to activate language material but also to broaden the content of the material. Therefore, at this stage, creative tasks will also be relevant.

The tasks we proposed for the aforementioned video for civil engineers are aimed at developing:

- speaking skills (Make up a dialogue between a reporter and the technical director of the reconstruction project; between a reporter and a tourist. Create your own TV news report about the construction of one of the landmarks and present it in the classroom);

- writing skills (Write a journalist's report to a newspaper about the reconstruction project to help straighten the Leaning Tower of Pisa.) [7, p. 119; 10, p. 68].

\section{Conclusions}

The experience of using authentic video in ESP classes makes it possible to conclude that these materials increase students' interest in learning English, help activate listening, speaking and writing skills and acquaint with the culture of other countries. The use of the authentic video intensifies the learning process and creates favourable conditions for the training of future civil engineers to for professional communication in English. 
However, based on our experience of using such authentic materials while teaching ESP, we note that the method is more effective for students with a higher level of knowledge. When working with the video, such students not only get pleasure from viewing, but also work on improving their listening and speaking skills, broadening their horizons and acquire the necessary skills to communicate with representatives from different countries for their successful professional activity.

In our opinion, the technique of step-by-step use of the authentic video is required further investigation and improvement for the effective ESP learning by students of technical higher schools as well as the creation of complexes including selected videos on profession-oriented topics and a set of tasks to them which will facilitate the teachers' preparation and diversify ESP classes.

\section{References:}

1. Hrytsai A.M, Kolesnyk I.V. (2012) Vykorystannia video na zaniattiakh z praktyky usnoho ta pysemnoho movlennia (anhliiska yak druha inozemna mova) yak zasib motyvatsii do vyvchennia inozemnykh mov [Using video in foreign language classes for practicing oral and written speech (English as a second language) as a means of motivation for studying foreign languages]. Naukovi zapysky Nizhynskoho derzhavnoho universytetu im. Mykoly Hoholia. Seriia : Psykholohopedahohichni nauky. [Bulletin of Nizhyn Mykola Hohol State University. Pedagogy and Psychology] (electronic journal). no. 2, pp. 77-81. Retrieved from: http://nbuv. gov.ua/UJRN/Nzspp_2012_2_21 (accessed 02 March 2018).

2. Zelenska O. P. (2015) Vykorystannia inshomovnykh avtentychnykh materialiv u protsesi kulturolohichnoi pidhotovky kursantiv VNZ systemy MVS Ukrainy [Using the foreign authentic materials in the process of the culturological training of the cadets at the higher educational establishments of the Ssstem of the Ministry of Internal Affairs of Ukraine]. Visnyk Chernihivskoho natsionalnoho pedahohichnoho universytetu. Seriia : Pedahohichni nauky [Bulletin of Chernihiv Pedagogical University. Pedagogical Sciences], vol. 124, pp. 156-159.

3. Ivanova S. G. (2013) Video na urokakh inostrannogo yazyka - kak sredstvo razvitiya kommunikativnoy kompetentsii studentov [Video in the foreign language classes as means of the development of students' communicative competence]. Proceedings of the Universitetskiy kompleks kak regional'nyy tsentr obrazovaniya, nauki i kul'tury: Vserossiyskaya nauchno-metodicheskaya konferentsiya (Russia, Orenburg, February 1, 2013), Orenburg: OOO IPK “Universitet”, pp. 1960-1962.

4. Isupova M. M. (2016) Ispol'zovanie neigrovykh autentichnykh video-materialov pri obuchenii inostrannomu yazyku studentov neyazykovykh vuzov [Use of non-fiction authentic video materials in teaching foreign language to students of non-linguistic universities]. Historical and Social Educational Ideas, vol. 8, no. 2, pp. 148-153. 
5. Klymova O. (2011) Metodyka roboty z videomaterialamy na zaniatti z anhliiskoi movy vuzov [The methodology of work with video films at the lessons of the English language]. Problemy pidhotovky suchasnoho vchytelia [Issues of the Modern Teacher Training], vol. 1, no. 4, pp. 31-35.

6. Kovalenko N. S., Kolbysheva Yu. V. (2011) Etapy raboty s videomaterialami na inostrannom yazyke $\mathrm{v}$ tekhnicheskom vuze (na primere Instituta prirodnykh resursov TPU) [Stages of work with video materials in a foreign language in a technical institute of higher education (by the example of the Institute of Natural Resources of Tomsk Polytechnic University]. Filologicheskie nauki. Voprosy teorii i praktiki [Philological Sciences. The Issues of Theory and Practice], vol. 9, no. 2, pp. 85-88.

7. Konoplianyk L. M. (2017) Etapy roboty z avtentychnymy videomaterialamy u protsesi pidhotovky maibutnikh inzheneriv-budivelnykiv do inshomovnoho profesiinoho spilkuvannia [The stages of work with authentic video materials in the process of future engineers-builders' training for professional communication in a foreign language]. Pedagogical Sciences, vol. 2, no. 75, pp. 114-120.

8. Miasoid H. I. (2017) Robota $z$ avtentychnym nenavchalnym videofilmom na zaniatti z inozemnoi movy [The work with authentic non-educational video at an ESP]. Visnyk Dnipropetrovskoho universytetu im. Alfreda Nobelia. Seriia: Pedahohika i psykholohiia. Pedahohichni nauky [Bulletin of Dinpropetrovsk Alfred Nobel University. Pedagogy and Psychology. Pedagogical Sciences], vol. 6, no. 2, pp. 68-74.

9. Otroshchenko L. S. (2012) Vykorystannia videomaterialiv na urokakh nimetskoi movy u nemovnykh VNZ [Use of video materials on the German language lessons]. Vyshcha osvita Ukrainy u konteksti intehratsii do Yevropeiskoho osvitnoho prostoru [Higher Education of Ukraine in the Context of Integration to European Education Area], vol. 4, no. 37, pp. 355-360.

10. Shostak O. H., Konoplianyk L. M. (2017) Professional English of the Construction Industry. Kyiv: NAU.

11. Shtelmakh O. (2013) Videourok yak metod rozvytku komunikatyvnoi kompetentsii u studentiv tekhnichnoho vuzu na zaniattiakh inozemnoi movy [Video lesson as the method of development of communicative competence of students of higher educational institutions at the English classes]. Problemy pidhotovky suchasnoho vchytelia. [Issues of the Modern Teacher Training], vol. 2, no. 8, pp. 104-109.

12. Yarotskaya L. V. (2016) Inostrannyy yazyk $i$ stanovlenie neprofessional'noy lichnosti (neyazykovoy vuz) [A foreign language band formation of a non-professional personality (non-linguistic higher school)]. Moscow: TRIUMF (in Russian).

13. Adams, T. W. (1995). What makes materials authentic? Retrieved from: https://eric.ed.gov/?id=ED391389 (accessed 05th March 2018).

14. Bacon, S., Finneman, M. (1990). A study of attitudes, motives, and strategies of university foreign language students and their disposition to authentic oral and written input. Modern Language Journal, vol. 74, no. 4, pp. 459-73.

15. Gower, R., Phillips, D., Walters, S. (1995). Teaching practice handbook. Oxford: Macmillan.

16. Harmer, J. (2001). The practice of English language teaching. London: Longman. 